\title{
PREDICTING THE EFFECTS OF ATTORNEY FEE SHIFTING
}

\author{
ThOMAS D. ROWE, JR.*
}

\section{INTRODUCTION}

The law and economics fraternity, whatever controversies it has engendered, has demonstrated the value of applying its sharp analytical tools to a considerable range of legal issues. Unfortunately, some of the sharpest of the tools, such as complex equations and detailed economic models, reduce the accessibility of the work for many who might benefit from it. The formal analyses, however, are often a form of shorthand that can be duplicated to some extent in a common longhand-English; such a translation, if successful and not too cumbersome, may widen the audience for the fruits of economic analysis of legal problems. It may even reduce the threat of guilt pangs for those who have some interest in these matters yet have not mastered the most formidable and forbidding techniques"the vast majority, . . . a happy folk, to be envied by most of the minority classes."

One effort to which the application of economic analysis may be especially fruitful is predicting the likely effects of attorney fee shifting-the practice of making the loser pay at least a substantial portion of the winner's reasonable attorney fees. The United States is virtually alone among the industrialized democracies in having as its basic rule that each side pays its own lawyer, win or lose. $^{2}$ As we have thought about and experimented with more fee shifting, the literature has begun to contain a good deal of speculative and theoretical work, some of it of high quality. ${ }^{3}$ Still lacking, however, is a comprehensive and detailed effort at identifying and analyzing the major likely effects of fee shifting.

This article attempts to fill, or at least to advance the work of filling, that gap.

\footnotetext{
Copyright (C) 1984 Law and Contemporary Problems

* Associate Dean for Research and Professor of Law, Duke University School of Law. The bulk of the work for this study was done while the author was Fellow in Administration of Justice, Office for Improvements in the Administration of Justice, U.S. Department of Justice, 1980-1981. I am grateful to OIAJ and its successor, the Office of Legal Policy, for supporting my work and the conference at which this paper was presented, and to the Duke University School of Law for released tinie to pursue the work and for additional support for the conference. I wish to acknowledge with thanks the support and criticism of Professors Maurice Rosenberg, John Leubsdorf, Kevin M. Clermont, Donald L. Horowitz, Dale A. Oesterle, and Richard Schmalbeck; Dr. Bruce Owen; and Philip H. Mause and Peter F. Rient. The views expressed here are my own and do not necessarily represent the position of the Department of Justice.

1. H. Fowler, A Dictionary or Modern English Usage 579 (E. Gowers 2d ed. 1965) (describing "those who neither know nor care what a split infinitive is").

2. See, e.g., Rowe, The Legal Theory of Altomey Fee Shifling: A Critical Overview, 1982 DUKE L.J. $651,651$.

3. See, e.g., Mause, Winner Takes All: A Re-Examination of the Indemnity System, 55 IowA L. REV. 26 (1969); Shavell, Suit, Settlement, and Trial: A Theoretical Analysis Under Alternative Methods for the Allocation of Legal Costs, 11 J. Legal. STud. 55 (1982).
} 
It surveys the possible impacts of principal varieties of fee shifting systems on prospective claimants' propensity to pursue legal claims and on the likelihood, timing, and amount of settlement once a claim is pursued. ${ }^{4}$ The article draws considerably on the work of several others; it also tries, in some instances, to push the analysis further than has been done elsewhere or to carry it into areas where little work has been done, such as the effect of offer of judgment devices affecting liability for attorney fees. It uses textual explanations and occasional numerical examples, but no equations (not even in footnotes or appendices!). The survey, I hope, will be of value in its own right in bringing together and advancing analysis of these matters; if it ever becomes possible to do empirical work, the need for which has been noted for decades, ${ }^{5}$ these predictions can also supply hypotheses for testing.

Thinking about the effects of attorney fee shifting is surprisingly complex and subject to enough pitfalls that a long and premonitory discussion sorting out several factors seems regrettably necessary. The following sections identify several variables which may influence the effects of an attorney fee shifting system.

\section{A. Types of Fee Shifting Systems}

American lawyers have become quite accustomed to the American rule that, as a general matter, each side bears its own attorney fee expenses. Those with some interest in the subject at times find the English practice, which is at an opposite pole as its basic rule requires that the loser pay at least a substantial portion of the winner's attorney fees, to be the most prominent example of a different system. Perhaps as a result, some discussion of the topic seems to proceed as if the choice is only between these two models. ${ }^{6}$ As the numerous "one-way" American federal and state fee shifting statutes 7 illustrate, however, variations from the American and English paradigms are possible. Moreover, the variations can have significantly different effects from those thought to be achieved by the polar choices; concern over some of the ill effects of one or the other need not compel a retreat to the opposite pole.

The four basic models are the American rule of no fee shifting, the English idea

4. In focusing on these suit and settlement effects, the article does not presume that they are the only significant ones. See also, e.g., Braeutigam, Owen, \& Panzar, An Economic Analysis of Alternative Fee Shifting Systems, Law \& Contemp. Probs., Winter, 1984, at 173 (economic model for impact of different fee shifting systems on expenditures in litigation). Nor need significant effects be confined to litigation processes; fee shifting might increase both the likelihood of suit against, and the size of recoveries from, those tempted to engage in, say, small chiseling of numerous consumers. The threat of more and costlier litigation might provide an effective deterrent to objectionable primary behavior. And in a significant work in progress, Professor Robert Prichard suggests that different fee rules can influence the content of, approaches to, and pace of development of substantive law. Prichard, A Systemic Approach to Comparative Law: The Effect of Cost, Fee and Financing Rules on the Development of the Substantive Law (Jan. 7 , 1984) (unpublished paper presented to Section on Comparative Law, Association of American Law Schools).

5. See, e.g., McCormick, Fees and Other Expenses of Litigation as an Element of Damages, 15 MiNN. L. REV. 619, 642 (1931); Sands, Atlomeys' Fees as Recoverable Costs, 63 A.B.A. J. 510,515 (1977).

6. See, e.g., Corboy, Contingency Fees. The Individual's Key to the Courthouse Door, Litication, Summer 1976 , at 27.

7. See, e.g., 29 U.S.C. $\$ 216$ (b) (1982) (in minimum wage, maximum hour, and sex discrimination in wages litigation, prevailing plaintiff to be awarded reasonable attorney's fee from defendant). 
of "two-way" shifting, and "one-way" approaches providing for fee awards to prevailing plaintiffs or defendants only. ${ }^{8}$ Each of these basic approaches can be modified by other key types of attributes, such as: (i) the breadth of applicability of the scheme; (ii) the standard for whether or not the court should award fees; (iii) the availability of offer of judgment devices affecting fee liability; and (iv) the method of calculation for fees to be shifted. ${ }^{9}$

A fee rule can apply across the board to all or nearly all civil litigation (as is true, for example, of the English rule), or only to certain types of actions (as with the Civil Rights Attorney's Fees Awards Act ${ }^{10}$ ), or to certain aspects of civil proceedings (as is the case for fee shifting as a discovery sanction under Federal Rule of Civil Procedure 37). Fee awards can be mandatory upon the success of one side on an issue or in the litigation, or in the court's discretion with various possible standards to guide the decision. The offer of judgment device does exist in this country in Federal Rule of Civil Procedure 68 and counterpart state rules, but it normally affects liability only for post-offer costs and not for attorney fees. ${ }^{11}$ This limited effect probably explains the relatively infrequent use of offers of judgment. In England, a parallel device is known as "payment into court" and enables a defendant to recover fees from a plaintiff who rejects the offer and does not do better at trial. This device apparently is used considerably and is quite effective. ${ }^{12}$ Also, methods of calculation can vary widely. This diversity runs from attempts to

8. As a practical matter, it is highly unlikely that this country will ever see widespread adoption of general two-way fee shifting. Still, it seems worthwhile to consider the likely effects of a two-way schemeboth to make clear the range of choices and their contrasting effects and because two-way schemes do exist in some situations. See, e.g., Alaska R. Crv. P. 82 (general two-way rule in Alaska); Ariz. Rev. Stat. ANN. $§ 12-341.01$ (1982) (two-way shifting in contract actions); CAL. CIV. Code $\$ 1717$ (West Supp. 1983) (two-way shifting whenever contract specifies one-way shift); FLA. STAT. ANN. $\S 768.56$ (West Supp. 1983) (two-way shifting in medical malpractice actions).

Though one-way schemes favoring prevailing defendants do exist, they are rare enough in practice and unappealing enough for most situations that this paper will give them little consideration and will use the term "one-way" to refer to pro-plaintiff provisions. For an example of a one-way pro-prevailing-defendant provision, see lLL. ANN. STAT. ch. 17, ๆ 6102 (Smith-Hurd 1981) (awards to prevailing defendant credit card holders sued for unauthorized use liabilities by card issuers). The likely effects of such provisions could easily be deduced by reasoning parallel to that used here and elsewhere for other approaches. For analysis of some of the probable impacts of one-way pro-prevailing-defendant provisions, see Shavell, supra note 3 .

9. For more detailed discussion of features of attorney fee arrangements generally, see Rowe, Attorney Fee Arrangements and Dispute Resolution (Oct. 1982) (paper prepared for National Conference on the Lawyer's Changing Role in Resolving Disputes, Cambridge, Mass., sponsored by National Institute for Dispute Resolution, American Bar Association Section on Litigation, and Harvard Law School; publication forthcoming 1984 in book based on conference papers). For treatment of the possibilities of using fee calculation methods to encourage desirable litigation behavior, see id.; Clermont \& Currivan, Improving on the Contingent Fee, 63 Cor NELl L. Rev. 529 (1978); Leubsdorf, The Contingency Factor in Altomey Fee Awards, 90 YALE L.J. 473 (1981).

10. 42 U.S.C. $\S 1988$ (1982).

11. The federal Judicial Conference Advisory Committee on the Federal Rules of Civil Procedure has recently proposed amendments to Rule 68 that would enable plaintiffs as well as defendants to use the rule and would make attorney fees recoverable in cases involving offers rejected and not bettered in the final judgment. Preliminary Draft of Proposed Amendments to the Federal Rules of Civil Procedure, 98 F.R.D. 339, 361-67 (1983) [hereinafter cited as Preliminary Draft].

12. See Zander, Payment into Court, 125 NEw L.J. 638 (1975). 
give full reimbursement on some market rate basis to explicitly partial reimbursement (as in some Canadian provinces ${ }^{13}$ ) to a percentage of the amount recovered (provided for by rule in Alaska, which has general fee shifting ${ }^{14}$ ).

\section{B. Situation Factors}

Commentators sometimes seem to assume that the impact of attorney fee shifting rules will be general in that more or less litigation, encouragement of settlement, or whatever will exist across the board. ${ }^{15}$ Indeed there may be some general effects, but more often the effects of a fee shifting policy are likely to depend on key aspects of the situation to which it applies. These "situation factors" are of three main types: (i) the characteristics of the adversaries; (ii) the relative significance of the fee amounts and the stakes in the litigation; and (iii) the parties' perceptions of the strength of their cases. ${ }^{16}$

1. Disputant Characteristics. Litigants come in different varieties and respond quite differently to the same economic incentives. In an important pair of articles, ${ }^{17}$ Marc Galanter has pointed out the distinction between "one-shotters" and "repeat players" in litigation. One-shotters are primarily individuals who do not make regular use of the courts or small entities that do not litigate frequently. Repeat players, by contrast, tend to be large and generally well financed organizations, particularly governments and larger businesses.

The significance of these party characteristics for present purposes is that they probably affect strongly both how a party will respond to various economic incentives and how parties interact. Generally, one-shotters are viewed as risk averse and repeat players as risk neutral. ${ }^{18}$ As later sections will discuss, differences in risk preference should have important effects on the readiness of potential plaintiffs to pursue a claim and, especially, on the prospects for settlement. Consequently, the strength and even the direction of the effects of fee shifting rules may well vary with the strength of the parties' risk aversion. ${ }^{19}$

13. See Williams, Fee Shifting and Public Interest Litigation, 64 A.B.A. J. 859, 861 (1978).

14. See Alaska R. Civ. P. 82.

15. See, e.g., Sands, supra note 5 , at 515.

16. For more detailed discussion of these "situation factors," see Rowe, supra note 9.

17. Galanter, Why the "Haves" Come Out Ahead: Speculations on the Limits of Legal Change, 9 LAw \& Soc'Y Rev. 95 (1974) [hereinafter cited as Galanter, Legal Change]; Galanter, Afterword: Explaining Litigation, 9 LAW \& SOC'Y REV. 347 (1975).

18. See, e.g., Galanter, Legal Change, supra note 17, at 99-100 \& n.11; H. Ross, SetTled OUT OF Court 214 (2d ed. 1980).

19. For those unfamiliar with this bit of economists' jargon, "risk preference" refers to parties' attitudes toward possible gain and loss under conditions of uncertainty. Someone who is "risk averse" in a situation will place a negative value on uncertainty, preferring a smaller sure thing to a larger possible gain with equal net expected value. Someone who is "risk neutral," by contrast, will be indifferent among choices with equal expected values. See Shavell, supra note 3, at 57-58.

Risk aversion is largely a function of diminishing marginal utility of income and wealth, which makes most middle-income individuals strongly risk averse in the face of the possibility of substantial loss. Thus introducing, for example, equal chances of greater gain and loss of a given absolute amount will normally make a middle-income person behave much more conservatively, while a wealthy party's conduct will be less affected.

These concepts imply important differences in the likely behavior of different kinds of parties. In litigation involving amounts small in relation to their total assets, large organizations_-"repeat players"-will usually be risk neutral. Many "one-shotters"-individuals with some assets but not great wealth-will 
2. Costs in Relation to Stakes. The larger the fee in relation to the amount at stake (or, in suits for nonmonetary relief, the importance to the litigants of the relief sought), the greater should be the influence of fee concerns. Of course parties' investment in litigation tends to rise as the stakes do, but-as one might expectthe increase in litigation costs is usually not proportional to the rise in the stakes. ${ }^{20}$ Consequently, the relative importance of the fee will normally be greater in smaller cases. ${ }^{21}$ The absolute size of the fee necessary to compensate adequately for a lawyer's time can readily make the pursuit of or resistance to a small or even medium-sized claim prohibitively expensive. ${ }^{22}$

3. Parties' Estimates of Case Strength. The expectation of unreimbursed litigation costs can bridge gaps between adversaries' anticipated returns from trial and make settlement attractive despite continued disagreement on the merits. Relative estimates of a case's strength on the merits, as to both liability and damages, will obviously influence the size of the gap that exists in the first place. Similarly, if a fee shifting rule applies, expectations about the outcome will influence whether a party foresees little chance of reimbursement-thus leaving expected litigation costs to play a gap-bridging role-or anticipates recovery of costs as well as success on the merits, reducing any gap-bridging effect.

\section{Types of Effects}

As recent theoretical writing has emphasized, ${ }^{23}$ it is important for analytical clarity to distinguish among different kinds of impacts that the various attorney fee shifting schemes could have. The most basic distinction is that between the decision by a prospective claimant whether to pursue a claim at all and the question whether the two sides, once a disputed claim is being pursued, will settle or go to trial. The first focuses on the incentives for a prospective plaintiff's side in isolation; the second, on the interaction of the two sides once a claim is being pressed and is not immediately conceded. The effects of fee shifting rules, moreover, can be either general or specific to certain types of situations; one-way pro-prevailingplaintiff fee shifting, for example, should encourage prospective plaintiffs, while two-way shifting should encourage strong claims and discourage weak ones.

Regarding settlements, much of the discussion in the literature appropriately focuses on the effect of fee shifting rules on relative likelihoods that the parties will settle or go to trial. Somewhat less prominently mentioned, but also significant, would be any effects on the stage in a dispute at which cases settle, as well as on the

normally find even moderate litigation expenses large in relation to their purses and will behave as risk averters, being especially sensitive to the chance of substantial loss.

20. See Cappelletti \& Garth, Access 10 Justice: The Worldwide Movement to Make Rights Effective-A General Report, in 1 ACCESS TO JUSTICE 3, 13 (1978) ("the ratio of costs to amount in controversy steadily increases as the financial value of the claim goes down"); Kritzer, Fee Arrangements and Fee Shifting: Lessons from the Experience in Ontario, LAW \& CONTEMP. PROBS., Winter 1984, at 125.

21. Wills \& Gold, Attomeys' Fees in Litigation: Time to Discard the American Rule?, LiTigation, Spring 1978 , at 31,60 . 16.

22. See, e.g., Rosenberg, Rient, \& Rowe, Expenses: The Roadblock to Justice, JuDGEs' J., Summer 1981, at

23. See Shavell, supra note 3 . 
amount at which settlements were reached. The probable influence of an offer of settlement device which affects liability for post-offer fees also needs to be considered for all of these kinds of effects on settlement.

The expected or actual effects of a fee shifting scheme are not, of course, the only factors that should influence policy decisions on whether and in what ways we ought to move away from the American rule. Ideas of fairness, consistency with remedial doctrines of full compensation and deterrence, and promoting the enforcement of public policy also may appropriately play a role. ${ }^{24}$ The effects on pursuit and settlement of claims, however, are an important factor to weigh and deserve extended discussion on their own.

\section{Common Fallacies}

John Leubsdorf observes in his contribution to this symposium that the record of forecasts about the effects of attorney fee shifting is full of errors and contradictions. $^{25}$ Lest that accurate observation persuade the reader that nothing attempting such predictions deserves any credence, this section identifies common fallacies in thinking about the likely effects of fee shifting rules to help save readers (and the writer) from reinventing the flat tire. In the past, a major source of error may have been the simple unsophistication in economic reasoning; today the spread of law-and-economics training reduces the forgivability of this sort of mistake.

Beyond that source of error, two specific types of confusion have repeated themselves in the literature on attorney fee shifting. First, in understandable eagerness to say something about an area of perhaps not fully perceived complexity, some have simply overgeneralized by speaking of the overall effects on pursuit of claims or settlement when closer analysis would not support the generalization in its full breadth. Such generalizations overlook the different rules and situation factors pointed out earlier. Some combination of rule and situation may produce one result, while a different combination will yield quite another. Perhaps the best single illustration is the existence of conflicting general predictions of both more and less "discounting" of claims under fee shifting; in fact, both expectations seem well founded but under different and limited circumstances. ${ }^{26}$

A second type of fallacy, encountered in connection with discussion of settlement, is the failure to take into account the effects of fee rules on both sides. It is sometimes assumed, for example, that the threat of increased defendants' liability from a probable fee award will make it more likely that strong plaintiffs' cases will get settled. ${ }^{27}$ This type of thinking ignores the plaintiff's possible feeling that he can hold out for more; as this article reflects, ${ }^{28}$ basic economic reasoning demonstrates that with risk neutrality and disagreement over the likelihood of a fee shift

24. See generally Rowe, supra note 2.

25. See Leubsdorf, Toward a History of the American Rule on Altomey Fee Recovery, LAW \& CONTEMP. Probs., Winter 1984, at 9.

26. See infra text accompanying notes 98-104.

27. See, e.g., Note, Attomey's Fees: Where Shall the Ultimate Burden Lie?, 20 VAND. L. REV. 1216,1222 (1967).

28. See infra text accompanying notes 65-77. 
the gap between the parties will actually be wider than under the American rule, thus reducing the likelihood of settlement. (The prediction of encouraging settlement indeed may ultimately appear analytically sound under some conditions, especially when risk aversion is a major factor; the initial error in analysis, however, means that if the first-level prediction is right, it is right for the wrong reasons.)

\section{E. Coverage and Methods}

Much of the literature that attempts to predict the likely effects of attorney fee shifting schemes is the work of legal academics and practicing attorneys. Particularly before the past several years, their methods often consisted of fairly speculative reasoning based on intuitive judgments about the probable behavior of litigants and lawyers. Such efforts, though they have sometimes gone astray due to lack of analytical rigor, do not always deserve derision; especially when a significant type of situation is not highly complex, or when there is good enough reason to expect that a particular influence among many cross-cutting ones will dominate, armchair reasoning can produce useful working hypotheses. A good example is that two-way fee shifting, with a calculation of fee awards such as to yield amounts giving a market rate of return on lawyer time and not limited by the sum in controversy, should encourage the bringing of meritorious small claims (whether or not that is to be desired).

Yet intuition has its limits, and economic analysis of varying degrees of complexity can provide valuable additions to and checks on the results of less formal approaches. ${ }^{29}$ A good first illustration is a limit on the prediction of encouragement of meritorious small claims: two-way shifting will not cause all of them to be brought. Assuming risk neutrality, a prospective plaintiff should sue if his expected return from litigation is positive. A person with a $\$ 1,000 \mathrm{claim}$, a $90 \%$ chance of prevailing, and expecting legal fees of $\$ 600$ for each side should sue under a two-way rule, for his expected value from suing is $\$ 780$ (\$900, from the $90 \%$ chance of prevailing on the merits, minus $\$ 120$, from the $10 \%$ chance of having to pay both sides' fees). ${ }^{30}$ Reduce the value of the claim to $\$ 100$, however,

29. The economic focus of the discussion in this article does not reflect a presumption that factors of economic incentive alone determine decisions whether to pursue claims or to settle them once pursued. Particularly with regard to the decision whether to pursue a claim at all, noneconomic factors may be quite significant. See, e.g., Blankenburg, Legal Insurance, Litigant Decisions and the Rising Caseloads of Courts: A West German Study, 16 LAW \& Soc'Y REV.601, 622-23 (1981-82) (decision to pursue claim appears to depend more on social cost to possible ongoing relations than financial concerns; lawyers are retained and claims pursued when situations are anonymous, as with traffic accidents, or when social ties are already broken, as with divorce). While noneconomic factors, often difficult to analyze systematically, may well play a role, economic incentives still seem highly likely to remain significant influences, worthy of careful analysis, in a broad range of situations.

30. The use of precise percentages and numbers in examples is not to imply that litigants and lawyers do, can, or should figure in such exact terms, although some regular litigants like insurance companies probably try to do so to some extent. The type of reasoning reflected in the illustrations, however, is what rational parties and counsel should and probably often do follow; the numbers help demonstrate the kind of net effect that can be expected from such thinking, even if it is in reality carried on in more approximate terms. 
and even the high probability of victory should not be enough to get the prospective plaintiff to sue; his predicted net from suit has gone to $-\$ 30$, since his expected return is now only $\$ 90$ before the $\$ 120$ allowance he should make for fees. ${ }^{31}$

Moreover, economic reasoning can sometimes yield results that at first seem counterintuitive but nonetheless appear sound. Sparing the reader the details for now, it can be shown that in certain situations making available an offer of judgment device, meant to encourage settlements, actually reduces the likelihood of settlement. ${ }^{32}$ And the complex Braeutigam-Owen-Panzar model for societal expenditures in another article in this symposium predicts that, assuming risk neutrality, adoption of a one-way pro-prevailing-defendant rule (presumably to discourage nuisance litigation) would yield higher expenditures on litigation in any litigated case, ${ }^{33}$ despite the intuitive sense that such fee shifting would discourage weak claims. ${ }^{34}$

Yet economic analysis, too, has its limits. Sometimes it will be possible to design a model for a situation, but the model will yield no determinate forecast for the direction of the effect of a change in some variable. It may remain valuable in empirical research to look for effects attributable to the change and may even be possible to find them, but economic reasoning will have produced no hypothesis about their direction. Further, to get determinate results it may be necessary to make assumptions that are contrary to fact and thus to restrict a model's ability to make predictions about the real world. The Braeutigam-Owen-Panzar model's assumption of risk neutrality is an example, although it hardly reduces the model's practical value to zero. For instance, litigation involving commercial firms opposing each other is a circumstance in which the assumption may reasonably approximate reality.

Finally, both speculative and formal efforts can be defeated when there are cross-cutting influences of uncertain magnitude. The prospect of fee shifting when the parties have differing estimates of the likelihood of the shift, for example, will drive them farther apart than they would be with no shifting, reducing the chances they will settle. But, as is so often the case, other things may not be equal; risk aversion, and possibly other factors, will cut the other way and offset the reduction in likelihood of settlement, though the extent to which they will do so seems subject to estimation in advance only by guesswork about the strengths of the various effects.

31. See R. Posner, Economic Analysis of Law $\$ 21.8$, at 451 (2d ed. 1977). For an illustration of how economic analysis can refine discussion like that in the text even further, see P'ng, A Model of Suit, Settlement and Trial in the United States Legal System 21 (Apr. 1983 revision) (Working Paper No. 5, Stanford Law School Law and Economics Program) (possibility of favorable settlement can make filing claim rational even if expected return from trial is negative).

32. See infra text accompanying notes $118-20$.

33. See Braeutigam, Owen, \& Panzar, supra note 4, at 180.

34. It probably would do so, and the increased expenditure might not be bad; most of it would likely come from defendants, who would have an increased incentive to resist nuisance claims, and they would usually have a claim to reimbursement for their fees. 
II

\section{Effects on Pursuit of Claims}

\section{A. General Effects}

As later discussion will reflect, many of the most significant effects of fee shifting on prospective claimants' inclination to resort to law could be expected in specific types of cases (such as meritorious small claims) and could work in different directions (encouragement of meritorious small claims and discouragement of nuisance suits under a two-way rule). Still, one rule seems likely to have a uniform effect on pursuit of claims. That is not the English two-way approach, despite occasional unqualified assertions that it would encourage or discourage litigation. With a two-way rule there are so many cross-cutting effects and factors-encouragement from possible recovery of one's own fees, discouragement from possible liability for an adversary's fees, the presence or absence of risk aversion-that no general prediction of the relative overall effects of the American and English rules on the likelihood that prospective plaintiffs will pursue claims seems possible. ${ }^{35}$

The approach that should uniformly encourage the pursuit of claims of all sorts in all situations is a one-way pro-prevailing-plaintiff rule. Such a policy permits plaintiffs to expect greater net recoveries, without adding a counterbalancing threat of loss. ${ }^{36}$ While the likely direction of the impact is obvious, the more significant question is whether empirical research could ascertain anything about its strength-that is, whether a change from the American rule to one-way shifting seemed to produce a large, small, or imperceptible increase in pursuit of claims, and whether the effect varied noticeably according to the type of suit. Impacts should be greater in smaller cases, in which the fee is more significant compared to the stakes.

Effects on the pursuit of claims can also come about more indirectly than through simple impact on likely net recovery, such as by determining whether a prospective plaintiff faces any substantial risk of loss and by influencing how attractive a case is for a lawyer to take. For the middle-income litigant, to whom the risk of having to pay costs would be a major deterrent, the difference between American and one-way rules on the one hand, and the two-way approach with its threat of substantial costs on the other, should be quite significant. ${ }^{37}$ Moreover, whether a lawyer is willing to get involved will often make the difference between

35. Cf. Shavell, supra note 3, at 59 (relative frequency of suit under American and English rules should be influenced by estimated likelihood of success); id. at 62 (risk aversion a stronger factor in decisions whether to pursue claims under English rule than under American practice).

36. For theoretical support of this prediction, see Shavell, supra note 3, at 60-61. The text presumes no cancelling effects-it is conceivable, say, that American damage awards are now widely inflated by judges and juries because they know fees must come out of recoveries, and that widespread fee shifting would eventually reduce or eliminate this inflation. It seems unlikely that such a phenomenon is now so prevalent, and that any offset would so completely cancel the impact of fee awards, as to eliminate the effect a one-way rule would have in encouraging prospective plaintiffs to press claims.

37. Cf. Pfennigstorf, The European Experience with Altorney Fee Shifting, LAw \& ConTEMP. PrOBS., Winter 1984, at 37, 78 (citing German study indicating that legal expense insurance, by removing threat of having to pay costs, encouraged seeking of legal advice and suing). 
a case's being pursued or not. Under the American rule, several types of cases hold out little prospect for a lawyer's being paid adequately: small claims, even strong ones; pursuit of strong nonmonetary claims; and defending cases for the nonwealthy. If a fee award rule makes it possible for a lawyer to expect payment in such a case, it should alleviate the present problem of having to turn down such cases or to take them on a losing or pro bono basis.

\section{B. Effects on Pursuit of Particular Types of Claims}

The effects of fee shifting should be most pronounced, obviously enough, when the size of the fee looms large in the calculations of the parties in relation to other relevant factors. Sometimes, of course, fees will run high compared to the amount in controversy even in a fairly big case; and litigation for high stakes will naturally tend to draw higher legal expenditures from the contestants. Still, the relative significance of fees and fee shifting rules usually should be greater in litigation toward the lower end of the scale; ${ }^{38}$ it is certainly worth spending much more on a ten million dollar case than on one for ten thousand dollars, but rarely is the expenditure likely to be a thousand times as great.

This relation is reflected in the way that much discussion of fee shifting's effects on particular types of claims focuses on three varieties-strong small claims, nuisance suits, and medium-strength claims of middle-income litigants. With the first, the probable fees likely are large in relation to the entire amount in controversy, which tends to make small claims not worth litigating for whoever faces the prospect of paying the fees. "Nuisance" suits facially may be for a large amount, but their low chance of success at trial gives them a relatively low settlement value - perhaps in the same range as the defendant's trial, or even just pretrial, fees. And for a middle-income litigant facing some possibility of an adverse fee shift, the size of the fee in relation to his assets takes on special importance since defeat may wipe him out financially. This section examines the likely effects of the principal types of fee shifting schemes on each of these three types of claims.

1. Strong Small Claims. The basic economics of the common hypothesis that fee shifting (pro-defendant rules aside) encourages the pursuit of strong small claims ${ }^{39}$ are straightforward. Under the American rule, with the plaintiff normally certain of paying his own lawyer, such claims are not worth pursuing unless their expected return significantly exceeds the likely fee. ${ }^{40}$ Given the cost of legal services, the amount of the claim must normally be fairly sizeable before it is worth pursuing. ${ }^{41}$ At the opposite extreme, one-way shifting should considerably encourage the pur-

38. See supra note 20 and accompanying text.

39. The classic piece urging fee shifting because of the help it would presumably give to the claims of the "little man" is Ehrenzweig, Reimbursement of Counsel Fees and the Great Society, 54 CALIF. L. REV. 792 (1966). See also, e.g., Mause, supra note 3, at 33-34; Posner, An Economic Approach to Legal Procedure and Judicial Administration, 2 J. LEGal STUd. 399, 437-38 (1973); $c$. Comment, Award of Allomey's Fees in Alaska: An Analysis of Rule 82, 4 UCLA-ALASKA L. REV. 129, 162 (1974) (American rule discourages litigation of small claims).

40. The words "significantly exceeds" are used because usually people will not invest their time and psychic energy in a lawsuit for only a small expected net financial gain.

41. See, e.g., Rosenberg, Rient, \& Rowe, supra note 22, at 17. 
suit of this type of claim. The prospective plaintiff's side faces only a small chance of loss, and that loss would be only the plaintiff's own fee and not those of both sides. ${ }^{42}$

Two-way fee shifting, similarly, makes a strong small claim more financially attractive than under the American rule, since the large chance of recovering a plaintiff's own fees usually more than offsets the small possibility of having to pay the fees of both sides. ${ }^{43}$ It is sometimes overlooked, however, that the English rule widens the range of potential outcomes and worsens the possible down side from defeat, and risk aversion is likely to be strong among small claimants. ${ }^{44}$ It seems impossible, without considerable empirical research, to be certain about the net effect of such countervailing pressures. For claims above the smallest that appear very strong, however, the English rule should be somewhat more encouraging than the American policy, although clearly less so than a one-way rule. ${ }^{45}$

Whether we should seek a change in our fee shifting policies in order to encourage the resolution of small claims through more or less conventional judicial processes, as opposed to trying to work out some alternative form of handling them quickly and inexpensively, is another matter. ${ }^{46}$ Quite possibly, strong small claims would settle at such a high rate that encouraging a good many more of them would serve the ends of justice without swamping the courts. ${ }^{47}$

42. This sense of the probable effect of one-way shifting on pursuit of small claims, along with a purpose to encourage such claimants, presumably lies behind the one-way small claim fee shifting statutes in effect in some states. See Idaho Code § 12-120(1) (1979); N.C. Gen. Stat. § 6-21.1 (1981); Or. Rev. STAT. $\S 20.080(1981)$

43. Compare the example given in the text accompanying note 30 supra, assuming the English twoway rule, with the same situation under the American rule: The plaintiff's expected net from suit with no shifting is just $\$ 300$, from the $90 \%$ chance of recovering $\$ 1,000$ minus the $100 \%$ chance of having to pay the plaintiff's lawyer a $\$ 600$ fee. Suit is thus much less attractive on a purely arithmetical basis than with twoway shifting, which makes the expected value of suit $\$ 780$.

44. See, Derfner, The True "American Rule": Drafting Fee Legislation in the Public Interest, 2 W. NEW ENG. L. REV. 251,256 n.16 (1979).

45. See Shavell, supra note 3, at 59-61. But if defendants' fees tended to run quite high and would be substantially reimbursed in the event of successful resistance, two-way fee shifting could be a significant deterrent even to quite strong small claims.

46. See, e.g., R. POSNER, supra note $31, \S 21.8$, at 451 (class actions more efficient); Devlin, Foreword, to Justice, Going to Law: A CritiQue of English Civil Procedure v, v-vi (1974) (some disputes, including many middle-range cases, uneconomical for even cheapest forms of litigation); Zander, Costs of Litigation: A Study in the Queen's Bench Division, 72 LAW SOC'y GAZETTE 679, 684 (1975) (noting high relative cost of counsel fees in smaller cases and raising question of need for more cost-effective mechanisms); Comment, Court Awarded Attomey's Fees and Equal Access to the Courts, 122 U. PA. L. REV. 636, 651 (1974) (questioning desirability of encouraging litigation of small claims).

47. See, e.g., Mattis, Altomey's Fees as Costs in Illinois: 1607 and All That, 1979 S. ILL. U.L.J. 249, 281; Mause, supra note 3, at 34; Posner, supra note 39, at 439.

To put the point in text in greater detail, strong small claims are almost always not worth litigating fully because the costs are excessive (unless the claims can be aggregated). It is usually appropriate that small claims not be fully litigated. But such dispositions can come about in two main ways. The American rule makes plaintiffs unlikely to pursue a strong small claim because the unrecoverable costs of a lawyer's time will exceed any likely recovery. A recalcitrant defendant can feel that the plaintiff's threat to pursue the claim despite resistance is hollow. By contrast, the prospect for a fee award that would compensate the plaintiffs lawyer adequately for time reasonably spent to overcome the defendant's resistance will make the threat to litigate a credible one; then, the way a strong small claim should most often be settled without full litigation is by the defendant's realizing that it is not worth fighting. 
2. "Nuisance" Suits. Another frequent prediction is that fee shifting would discourage "nuisance" litigation ${ }^{48}$ or cases brought with little chance of success but, at least in part, in the hope of getting some payment because the defendant's unrecoverable attorney fees could run higher than the amount the plaintiff will accept to settle the case. ${ }^{49}$ Though the basic reasoning about the likely effect is easy to follow, the predictions need some refining. Moreover, there are economic objections to some of the common assumptions in this area that take reckoning with, although on closer analysis they do not appear to call the main hypothesis into question.

A standard objection to the American rule is that, in contrast to English-style fee shifting, it does not provide enough disincentive to nuisance litigation. Without any serious threat of a fee shift to a prevailing defendant, plaintiffs face no significant chance of loss from suing. Furthermore, their lawyers face nothing worse than the prospect of some uncompensated time, balanced against the chance of some gain from a settlement and the escape hatch of a voluntary dismissal at little or no $\operatorname{cost}^{50}$ if the going begins to look rough. A fee shifting scheme that includes at least some element of possible pro-defendant shifting, by contrast, introduces the danger that a plaintiff will actually be out of pocket a substantial sum, which should force potential plaintiffs with weak claims to think twice before proceeding. ${ }^{51}$

Of course, not every fee shifting scheme will discourage weak claims by comparison with the American rule; pure one-way pro-prevailing-plaintiff shifting suffers from the same lack of disincentives as does the denial of all fee shifting. Such a one-way policy should not encourage nuisance suits much more than the American rule because the chance of recovering fees should appear small; but the effect, however minor, could only be in the direction of more encouragement for nuisance litigation. Thus in a nutshell, on first consideration the hypothesis is that two-way shifting should provide substantial disincentives to the pursuit of quite weak claims, compared to the American rule, which in turn should be slightly less encouraging to such claims than a one-way regime.

Economic reasoning provides a basis for questioning the premise of the argument that under the American rule there is little disincentive to the pursuit of nuisance claims. If such claims already are fairly strongly discouraged, they should be few in number and the addition of one more deterrent should make relatively little difference. A first argument supporting the belief that there already should be little nuisance litigation is that the bringing of such claims presumes an irrational degree of willingness to bluff and be bluffed. Second,

48. See, e.g., Kuenzel, The Attomey's Fee: Why Not a Cost of Litigation?, 49 IowA L. REV. 75, 78, 85 (1963); Shavell, supra note 3, at 59-60 \& n.19; Comment, supra note 39, at 162-63; P'ng, supra note 31 , at 22.

49. See, e.g., D. Dobbs, Handbook on the LaW of Remedies: Damages-Equity-Restitution § 3.8, at 201 (1973); Bodine, Losers Get Legal Tab in Florida, Nat'l L.J., July 7, 1980, at 1, col. 4; Wills \& Gold, supra note 21 , at 31 ; P'ng, supra note 31 , at 2-3.

50. See, e.g., FED. R. CIV. P. 41 (a) (conditions for voluntary dismissal without prejudice); FED. R. CIV. P. 41 (d) (provision for payment of other side's costs from prior voluntarily dismissed action only upon second filing of claim); $f f$. P'ng, supra note 31 , at 11 (if suing and dismissing were costless, on economic analysis prospective plaintiffs should always sue).

51. See Posner, supra note 39 , at 437. 
contingent fee arrangements should mean that lawyers, if not clients, will be wary of pursuing weak claims; it is a money-losing proposition if the lawyer takes cases with one chance in ten of victory and likely average recovery of only, say, four times his investment in cases he wins. The absence of a substantial downside risk for clients does not mean that none exists for their lawyers or that attorneys can ignore the need for a substantial chance of gain to compensate for risk. The American rule, in sum, may not by itself provide much deterrence, but the above factors afford a good deal.

In support of the first argument, it can be urged that it makes sense to try bluffing only when the threat is credible; with "nuisance" suits, that credibility may be lacking since the plaintiff's side has to appear willing to throw away good money in the form of the plaintiff's lawyer's probably-not-to-be-compensated trial time. ${ }^{52}$ If the defendant thinks the plaintiff really will take the case to trial, it is rational under the American rule to settle for the defendant's expected trial costs or less; but the defendant should be able to believe that the plaintiff will hesitate first since he must take the initiative of carrying the case forward to trial. A further deterrent to bluffing with nuisance suits is that repeat player defendants have reason to develop a reputation for toughness in order to deter weak claims; ${ }^{53}$ for them it can even be rational to spend more defending against some weak claims than they expect to pay if they lose. Thus, if little reason exists to expect much nuisance litigation without fee shifting, a change in practice should not make much difference.

These points are plausible, but most lawyers with experience in the defense of civil cases - and that includes myself--would likely insist that there is some noticeable amount of nuisance litigation. Moreover, an empirical study of insurance company settlement practices confirmed a willingness on the part of insurers, after initial posturing about refusing to pay "nuisance value," to go ahead and do just that. ${ }^{54}$ Defendants also can have economic reasons, apart from fees, to settle such suits, such as avoidance of bad publicity. Similarly, plaintiffs may be acting at least partly out of noneconomic motives, such as spite or desire for vindication. Differences can also arise between the positions of lawyer and client that would explain continuation of a nuisance suit. The lawyer may have taken the case on a contingent basis when it appeared quite tenable; if it later weakens without coming to seem frivolous, though, the lawyer is not ethically free to withdraw ${ }^{55}$ and may be unable to persuade the client-who has little to lose if not threatened with adverse fee shifting-to drop the case.

Some realities of litigation, moreover, provide reason to think that discouragement of nuisance suits under the American rule may often not be enough to keep them from being brought. Even if it would not be rational for a plaintiff to pursue a weak case all the way through trial, and hence a defendant should not believe a threat to do so, it might cost the plaintiff little and the defendant a good deal to go

52. See id. at 432-33.

53. See P'ng, supra note 31 , at 20.

54. See H. Ross, supra note 18, at 204-05.

55. See Model Code of Professional Responsibility DR 2-110(C) (1980). 
as far as the defendant's preparing a motion for summary judgment. ${ }^{56}$ Because of the low cost, a plaintiff could rationally push things to the point at which the defendant, believing the threat, could find it sensible (though galling) to settle for less than it would cost to carry things through the motion stage.

Finally, the plaintiff is not the only one whose threat may be less than entirely credible. If it becomes clear that plaintiff can be bought off at a modest price, the defendant also will be throwing away good money if he pays more than that to fight. Moreover, there is normally some inevitable degree of uncertainty on each side about the other's beliefs and intentions ${ }^{57}$ which makes it impossible to be sure that any threat is entirely lacking in credibility. Thus, at least some bargaining value remains in many weak claims and defenses.

The argument about the effect of contingent fees on nuisance litigation needs less extended treatment. The point validly made is that, since lawyers' fees in contingent arrangements depend on success, it is in their interest to give sound advice about the propsects and not to take cases that appear too weak. ${ }^{58}$ As one article making this point has added, though, the percentage feature of most contingent fees in this country can dangle before the lawyer a pot of gold brilliant enough, however distant, that it may impair judgment and overcome scruples. ${ }^{59}$ Moreover, a rational lawyer calculating the chances of success and giving straightforward advice would take into account the possibility of a modest settlement after little effort; victory at trial on an inflated claim is not the only possible sort of success relevant to the decision whether to pursue a "nuisance" suit. As mentioned above, the lawyer might also be in such a position that the client lacked sufficient incentive to take discouraging advice seriously.

The economic arguments for a low level of nuisance litigation under the American rule, while not lacking in force, thus do not seem to rule out the possibility of a significant effect resulting from a change to a system that involves the substantial likelihood of fee shifting against losing plaintiffs; its effect should be to discourage pursuit of weak claims. The tentative hypotheses stated at the start of this discussion, then, still seem viable, though the considerations just mentioned might influence the magnitude of the effects. Moreover, entirely apart from fee shifting rules, the economic constraints that low odds of success alone place on pursuing weak claims may result, even under a one-way approach, in nuisance claims not being pressed so often as to afford ground for much concern, particularly if a one-way

56. Cf. P'ng, supra note 31 , at 21 (even if expected return from trial is negative, plaintiff's suing can be rational given prospect of favorable settlement). See also Mause, supra note 3, at 55 (possible explanation for nuisance litigation is defendant's prospect of spending more than plaintiff).

57. See, e.g., S. Bacharach \& E. Lawler, Bargaining: Power, TaCtics, and Outcomes 172-73 (1981) (importance of information each side has about other to likelihood and effectiveness of bluffing); Priest, Regulating the Content and Volume of Litigation: An Economic Analysis, 1 Sup. CT. ECON. REV. 163,167 (1982) (defendant's uncertainty about plaintiff's assessment of chance of success and about likely litigation costs can make plaintiff's threat to litigate credible).

58. See Clermont \& Currivan, supra note 9, at 571-72; Corboy, supra note 6, at 32; Kreindler, The Contingent Fee: Whose Interests Are Actually Being Served?, 14 For UM 406, 407 (1979).

59. See Clermont \& Currivan, supra note 9, at 574; see also DeWees, Prichard, \& Trebilcock, An Economic Analysis of Cost and Fee Rules for Class Actions, 10 J. LEGAL STUD. 155, 182-83 (1981) (contingent percentage fee under American rule does not make uneconomical some class actions with very low chances of success). 
scheme included provision for a reverse shift against a plaintiff who unreasonably brought or continued a claim. ${ }^{60}$

3. Claims and Defenses of Litigants of Modest Means. In one sense, two-way fee shifting may do its job of discouraging nuisance litigation too well, or at least have disincentive effects beyond weak cases that should be discouraged. A common assertion is that the English rule, by comparison with the American, excessively deters the pursuit by middle-income litigants of reasonable, but not clearly meritorious, claims and defenses. ${ }^{61}$ The mechanism is simply that, given risk aversion and the diminishing marginal utility of income and wealth, the threat of having to pay the other side's fee can loom so large in the mind of a person without considerable disposable assets that it deters the pursuit of even a fairly promising and substantial claim or defense.

The most encouraging scheme for middle-income litigants' plausible but not clearly winning claims would be a one-way pro-prevailing-plaintiff rule. That approach would have the double attraction of assuring full recovery in the event of success while limiting the downside risk, in the event of defeat, to a plaintiff or his counsel's having to absorb the plaintiff's lawyer's fee. The American rule has the same attractive protection from large downside risk, but it reduces the possible net gain for the plaintiff or leaves the successful defendant owing the amount of his own lawyer's fee.

Two-way shifting in such situations has both an incentive and a disincentive lacking under the American rule: it offers the possibility of undiluted recovery or reimbursement for a successful defense, but the risk of loss is considerably greater because of potential liability for the adversary's legal fees. The net effect of this combination is uncertain; but for two reasons, on balance it seems highly likely to discourage the pressing of claims and defenses by those of modest means. First, risk aversion is probably strong among middle-income prospective litigants. Second, compounding that phenomenon for plaintiffs is the factor of where risk could fall under two-way shifting as compared with the American rule. Under the latter, most such litigation is handled with a contingent fee arrangement, which not only eliminates the risk of having to pay the defendant's fees but places the risk of having to absorb the plaintiff's fees in the event of defeat on the lawyer, who often handles several such cases at once. As a risk-spreader, he can afford to be more risk neutral than the client in individual cases. Unless ethical canons change ${ }^{62}$ or other means evolve to deal with the problem, ${ }^{63}$ however, the lawyer

60. See Christiansburg Garment Co. v. EEOC, 434 U.S. 412 (1978).

61. See, e.g., White, Contingent Fees: A Supplement to Legal Aid?, 41 MOD. L. REv. 286, 295 (1978); Wills \& Gold, supra note 21, at 34; sources cited in Rowe, supra note 2, at $656 \mathrm{n} .22$. Not all commentators think that discouraging such claims would necessarily be a bad thing. See Mause, supra note 3, at 36.

62. Compare Model Code of Professional Responsibility DR 5-103(B) (1980) (client must remain ultimately liable for most litigation expenses) with MODEL RULES OF PROFESSIONAL CONDUCT Rule 1.8(e)(1) (1983) (lawyer's advancing of court costs and litigation expenses with "repayment contingent on the outcome of the matter" permissible).

63. Two-way fee shifting's effect on the access of the middle class to justice, if quite significant in discouraging persons of modest means, would lead to market responses such as legal expense insurance to spread the risk of loss. See generally W. Prennigstorf, Legal Expense Insurance: The European Experience in Financing Legal Services (1975). 
cannot assume the risk of an adverse shift; the client, probably risk averse and particularly wary of dipping into savings or going into debt, will have to assume the risk. Finally, one-way pro-plaintiff shifting would be especially discouraging to those of modest means who are considering whether to stand on plausible but not clearly strong defenses, for this scheme has all of the negatives of the English rule without the prospect of possible reimbursement.

\section{III}

\section{Effects in Connection with Settlement}

Beyond the inclination of potential litigants to pursue claims, the second major area in which fee shifting policies should have significant impact is that of decisions whether to litigate or settle without trial once a claim is being pursued. This part of the article discusses probable effects on the likelihood of settlement, its timing, and the terms on which settlement may be reached. By separating out these different kinds of settlement effects, the article attempts to reduce some confusion in prior discussion that has sometimes spoken too generally in terms of "encouraging" settlements. Casual speculation that a change of fee shifting rules will improve prospects for settlement might be mistaken if, for example, "improvement" is meant as making prospects more promising, but the suggestion could rest instead on a valid insight that settlements should be reached at a different amount. And, as we shall see, a desired impact with respect to one of the three kinds of settlement effects may come with influence on one of the others that we would prefer to avoid.

The discussion in this part proceeds initially on the assumption, realistic in many jurisdictions, that formal offer of judgment devices affecting fee shifting are either unavailable or little used. A subsequent section then examines the offer device to arrive at forecasts of its effects as they coincide or differ with those of major fee shifting approaches that do not include an offer device. Though the offer device is broadly assumed to encourage settlements, ${ }^{64}$ it appears, in at least some significant situations, likely to make settlement less probable; even if that surprising result is correct, though, the offer device still may have enough positive effects on the timing and terms of settlements to deserve serious consideration.

\section{A. Without Offer of Judgment Device}

1. Likelihood of Settlement Versus Trial. One of the most common, but often least adequately considered, predictions about attorney fee shifting is that it would encourage settlements. ${ }^{65}$ This suggestion may at least in some circumstances be plausible, but examination of the influences at work is essential before arriving at that conclusion. To begin with, some speculative pieces make the elementary logical error of not taking into account the effects of fee shifting on the settlement

64. See, e.g., Preliminary Draft, supra note 11, committee note, 98 F.R.D. at 363.

65. See, e.g., Avilla, Shall Counsel Fees Be Allowed?' 13 ST. B. J. CAL. 42, 43 (1938); Epstein, Medical Malpractice: The Case for Coniract, 1976 AM. B. Found. Research J. 87, 135; Kuenzel, supra note 48, at 87; McCormick, supra note 5, at 642; Talmadge, The Award of Altomey's Fees in Civil Litigation in Washington, 16 Gonz. L. Rev. 57, 69 (1980). 
positions of both sides. Instead they look only, say, at a defendant's fear of paying more in a strong case against him and assume from his presumable willingness to settle at a higher amount that the overall probability of settlement will be greater. ${ }^{66}$ The trouble is that it takes two to settle; the decision is one made not in isolation but in interaction with another who may also be affected by the incentives created by a fee shifting policy. As the defendant becomes willing to offer more than he would have without fee shifting, the plaintiff may also feel he can hold out for more than he would have demanded under the American rule. ${ }^{67}$ For purposes of determining the likelihood of settlement, the important factor is whether the parties are generally closer together or farther apart, not high or low.

To some readers, this sort of calculation may be unfamiliar. Therefore, some background on the theory of the role of litigation costs in settlement considerations may be helpful as an introduction to forecasting the effects of fee shifting policies on bringing the parties together or driving them apart. Obviously, if the parties agree on the likely outcome of a trial, it makes no sense for them to litigate rather than settle. ${ }^{68}$ If they disagree on the probable result and if litigation were completely costless to them, by contrast, it would always be rational for them to litigate. The threat of unreimbursed litigation costs can bridge the gap and make it sometimes economical for both parties to settle with each other despite unresolved disagreement, by rendering settlement at least no less favorable on balance than the expected net result of trial.

To give an example under the American rule, if you have a claim against me for $\$ 1,500$ that will cost us each nothing to settle and $\$ 1,000$ to litigate, even if each of us feels positive of victory we should rationally settle the case. Your expected net from trial is a $\$ 500$ gain, the claim minus the cost; my expected net loss is $\$ 1,000$ from no damages but with the loss in unrecoverable counsel fees. It is then economically rational for us to agree to forego trial, with me paying you something in the $\$ 500$ to $\$ 1,000$ range; if we do that, each of us is at least no worse off than we would expect to be if the case went to trial. The $\$ 500$ overlap sometimes is referred to as the "bargaining span,"69 the range in which it makes economic sense for the parties to settle. The span can be positive, as in this example (in which case the parties have room to bargain); zero (in which event there is theoretically a single settlement point); or negative, in which case there is a gap between the parties and they should not settle, though they should perhaps reconsider their estimates. One approach to the question of the effects of fee shifting policies on the

66. See Note, supra note 27 , at 1222 .

67. See Posner, supra note 39, at 418-19 (raising stakes increases both plaintiff's demand and defendant's offer); Walker, Court Awarded Attomey's Fees Under the Private Altomey General Concept: A Defense Perspective, 23 U. Kan. L. REv. 653, 672 (1975). Sometimes, of course, a plaintiff's demand might rise little or not at all. If the prospect of a fee award brought the defendant's offer closer to full compensation, see infra text accompanying notes $97-103$ (less discounting of strong claims probable with fee shifting), a plaintiff with a noncontroversial claim might be readily satisfied and even inhibited by a sense of justice from holding out for more. Settlement could thus come more easily in such cases with fee shifting, though-illustrating the point in the text-it is necessary to think through the effects on both sides before reaching any conclusion.

68. See Shavell, supra note 3 , at 63 . The statement in the text presumes, as must virtually always be the case, that it costs more to litigate than to settle.

69. See Note, An Analysis of Selllement, 22 STAN L. REv. 67 passim (1969). 
likelihood of settlement is to consider whether one policy should have a positive or negative effect on the bargaining span compared to another; a negative effect, for example, will move some cases out of the range in which they should and probably would be settled under a different policy. ${ }^{70}$

In discussing these effects, we can initially put aside cases in which the parties agree on the likelihood and probable amount of a fee shift. ${ }^{71}$ Whenever the parties agree on the probability of a fee shift under a system allowing any form of shifting, the bargaining span is the same size as under the American rule. (It may be at a higher or lower level, but it is as many dollars wide.) In intuitive terms, this result makes sense because, if the parties agree on the probable amount and direction of a fee shift, their estimates both move the same amount in the same direction from the estimates they would make under the American rule, leaving the span and the prospects for settlement unchanged. ${ }^{72}$ The only impact on the likelihood of settlement in such a situation would come from risk aversion in one or both of the parties, since adding a possible fee shift widens the range of possible outcomes. The effect of risk aversion is to increase the chances for settlement (which should already be high, given the degree of agreement) under any system using a fee shift as opposed to the American rule. ${ }^{73}$

In considering the effects of fee shifting systems on settlement likelihood, the primary focus thus belongs on cases in which the parties disagree on the chance that fees will be shifted. The main emphasis, moreover, should be on cases in which the disagreement can be labeled "optimistic"-each side thinks better, not worse, of its own chances than the other does. Parties with a pessimistic disagreement will usually rush to settle, no matter what the fee shifting rule. ${ }^{74}$

70. For cases in which the bargaining span was experimentally narrowed but still remained positive, Raiffa reports that an agreement sometimes took longer but still was usually reached. H. RAIFFA, THE ART AND SCIENCE OF NEgotiation 57 (1982).

71. Such a case might be one in which the parties agreed on liability but disagreed on damages, and there existed no offer device by which they could affect their liability for fees.

If fee shifting is mandatory in favor of prevailing parties or prevailing plaintiffs, the probability of the shift coincides with the probability of prevailing on liability. When there need not always be shifting in favor of a prevailing party, as is often the rule even when there is some shifting, the two probabilities diverge; that for the shift should be used in calculations of the likely effect of a fee shifting scheme. Thus, a significance of both offer of judgment devices and judicial discretion in the decision whether to award fees is that they separate the likelihoods of prevailing on the merits and receiving an award of fees, adding a possible further source of disagreement between the parties and some complexity to the calculations of the impact of a fee shifting scheme.

72. Cf. Shavell, supra note 3 , at 78 (when parties agree on chances of prevailing, "then the likelihood of trials is not affected by the system determining payment of legal costs"). The statement in text presumes that the amount at which settlement is considered does not change so greatly as to elicit effects based on the parties' marginal utilities of wealth.

73. See id. at 68-69.

74. See R. POSNER, supra note $31, \S 21.4$, at 436 . Steven Shavell has demonstrated that in one type of situation involving a form of what this article calls "pessimistic disagreement," litigation remains possible-and that settlement would actually be more likely under the English than under the American rule. That situation occurs when the plaintiff has a lower estimate of the chances of prevailing on liability than does the defendant, but the plaintiff's expectation of the amount of damages that might be awarded in the event of victory is higher than the defendant's. As long as the likelihood of a fee award remains linked to the liability result in such a case (with an offer device available, it would not have to), the English rule does more to bridge the gap between the parties than does the American. See Shavell, supra note 3, at 66-67. 
For the preliminary development of predictions about the "optimistic disagreement" cases that seem the most significant, it is helpful to make some initial simplifying assumptions to be discarded later. These assumptions are that the parties are risk neutral, that a change in fee shifting policies has no effect on the amounts litigants spend on legal services, and that expenditure also has no effect on the parties' expectations for the outcome of trial. Under these circumstances, the effect on the bargaining span of any departure from the American rule can be shown to be negative-in short, fee shifting would engender more trials and fewer settlements, and two-way shifting should have the strongest impact. ${ }^{75}$

In intuitive terms, this effect makes sense-even if it may initially seem counterintuitive to some-because adding more factors about which the parties can and do disagree pushes them farther apart. To use the simple illustration sketched above, full two-way shifting would give the $\$ 1,500$ claimant sure of success a net expected gain from trial of $\$ 1,500$, the full award unreduced by legal fees. A defendant who was equally sure of his own success would expect to come out of trial with no net gain or loss, paying no award and having his fees reimbursed. ${ }^{76}$ The effect of the change in fee shifting policy, other things remaining unchanged in accordance with the assumptions, is to send the case from being one that should be settled with a positive bargaining span of $\$ 500$ to one that has a negative span (gap between the parties) of $\$ 1,500$. A one-way rule would have similar but smaller negative effects on the span; the plaintiff would retain his expectation of a net gain of $\$ 1,500$, while the defendant would expect a $\$ 1,000$ net loss from having to pay his own fees but not having to pay a judgment or plaintiffs fees, making the span $-\$ 500 .{ }^{77}$

75. See, e.g., R. Posner, supra note 31, $\$ 21.8$, at 452 (two-way shifting); Mause, supra note 3 , at 31 (same); Shavell, supra note 3, at 65-66, 67, 77-78, 79 Fig. 3 (two-way and one-way systems); Bebchuk, Litigation and Settlement Under Imperfect Information 21 (Nov. 1983) (Working Paper No. 15, Stanford Law School Law and Economics Program) (assuming risk neutrality, "[t]he likelihood of settlement is greatest under the American rule and lowest under the British rule"). For formulas usable to calculate the bargaining span under the English and American rules, see Note, supra note 69, at 92 . The formulas can be adapted for other fee shifting schemes.

76. Changing to more realistic intermediate estimates of the likely outcome would make differences of degree only, as long as there remained "optimistic disagreement."

77. Cf. Shavell, supra note 3, at 67 (probability of trial under one-way rules falls between the probability under the English and American approaches).

The direction of the effects discussed in the text remains the same at whatever point before the end of a litigation one considers them, but the magnitude can vary in different ways under different rules. Under the American rule, a rational decisionmaker choosing part way through litigation between settling and pressing on should factor in only expected future fees, disregarding those already incurred because they are unrecoverable. If, in the text example, it costs $\$ 500$ to prepare for trial and $\$ 500$ to try the case, the American rule plaintiff's expected net gain from going to trial once fully prepared is $\$ 1,000$ and the defendant's expected net loss only $\$ 500$, meaning that they now have a negative bargaining span of $\$ 500$ and should not settle even though they might have earlier. Under the American rule, in other words, the gap-bridging effect of expected unrecoverable fees shrinks as the case goes on and the parties incur their fee liabilities. (Improved information and changed estimates of likely success, of course, will often more than compensate for the loss of the gap-bridging effect from incurring fees.)

With full two-way shifting, by contrast, absent changes in estimates of success the expected net from trial remains the same throughout the litigation; since a party must anticipate being liable for or recovering sunk costs, they remain relevant in comparing the likely results of trial with possible settlement terms. Under a one-way rule, finally, the effects are mixed. Again, aside from changes in estimates of likely success. the expectations of the beneficiary of a possible shift will not change over the course of the litigation; the defendant, however, should consider only its own future fees (because it cannot recover past ones) but the plaintiffs total fees (because it may be liable for them all). 
The foregoing illustration is useful because it clearly displays the significant negative effect fee shifting will have, other things being equal, on the bargaining span. The example will not serve as a basis for realistic, general predictions, however, since the simplifying assumptions are obviously contrary to fact in at least a significant number of cases. Relaxing the assumptions may make it impossible to produce models that yield determinate predictions of the combined net effects of the various cross-cutting factors, but we can at least consider the direction of the effect of each relaxation and make some plausible speculations about the strength of the various influences.

The Braeutigam-Owen-Panzar model, assuming risk neutrality, predicts that any move away from the American rule will produce an increase in the level of expenditures in a contested case. ${ }^{78}$ By itself, such an increase would amplify the negative effect of fee shifting on the bargaining span ${ }^{79}$ since, whenever the parties disagree about a larger amount, the gap between them is obviously greater. ${ }^{80}$ Increased expenditure, however, can also have effects on estimates of likely success, effects that may influence the chances of settlement in different directions at the same time.

On the one hand, in ways such as improved presentation of one's own case, a greater investment in legal services can improve the odds in a party's favor (and seeing an opponent invest more can be a reason for pessimism). On the other hand, increased spending can produce information that permits more accurate estimates of the probable results of trial, the normal effect of which is to bring the parties closer together. ${ }^{81}$ Furthermore, it has been speculated that the greater penalty for mistaken estimating under fee shifting will produce the same effect of making both parties' estimates more realistic. ${ }^{82}$ For these reasons, estimates of success in the same case, under different fee shifting rules, might not remain the same. The signs point in enough different directions, however, to make confident predictions on the net effect of increased spending - if it indeed occurs-seem impossible.

No such ambiguous result would flow from relaxing the assumption of no risk aversion, which is probably common among non-wealthy individual litigants. ${ }^{83}$ Introducing any form of fee shifting makes possible a broader range of outcomes than under the American rule. By itself, that broadening will make a risk-averse

78. See Braeutigam, Owen, \& Panzar, supra note 4, at 180.

79. For a detailed illustration of the effects of such additional spending on the bargaining span, see Note, supra note 69 , at $77-78$.

80. This combination of factors seems to tie in with the sometimes-expressed concern that the English rule contributes to reciprocal escalation of litigation expenditures. See, e.g., sources cited in Rowe, supra note 2, at $656 \mathrm{n} .23$. The argument supporting this concern runs, in intuitive terms, that if you see me spending more to raise my chances of winning (as by filing motions, taking more discovery, etc.), the fact that you may have to pay my legal fees as well as damages may make you want to spend more yourself to avoid that expense and keep up your own chances of being indemnified. The American rule, of course, can also contribute in its own way to reciprocal escalation when each party thinks it may improve its settlement bargaining position by threatening the other side with moves that will increase its unrecoverable fees.

81. See, e.g., R. POSNER, supra note $31, \S 21.8$, at 453.

82. See id. at $452-53$.

83. The likely prevalence of risk aversion in such persons seems to underlie predictions of increased pressure on middle-income plaintiffs to settle under two-way shifting. See, e.g., Williams, supra note 13, at 862. 
party more inclined to settle, without having a contrary effect on the adversary, and thus make settlement more likely. ${ }^{84}$ The very same drive-apart effect that, by itself, worsens the odds for settlement has a double-edged impact when risk aversion is present; when people have something more to disagree about, they also have something more to worry about.

The role of risk aversion, however, cannot be considered in isolation. First, of course, it may keep some cases from being pursued; 85 in those very cases its settlement-encouraging effect could have been expected to be strongest, given that risk aversion is already present in at least one of the prospective parties. Second, its effect on plaintiffs under a one-way pro-prevailing-plaintiff rule, though present because of the broadening of the span of possible outcomes, should not normally be strong; assuming the likelihood of a sharp change in diminishing marginal utility of income and wealth at around the level to which one has become accustomed, ${ }^{86}$ the greatest impact from risk aversion could be expected to come from increasing the threat of loss, a danger absent under the one-way approach. And third, in encouraging settlement risk aversion is in a sense coming from behind since, in optimistic disagreement cases, fee shifting will already have had a negative effect on the bargaining span. Significant risk aversion, of course, could more than counterbalance that gap-widening effect, but outweighing this contrary force is precisely what risk aversion has to accomplish for the net effect on the chances for settlement to be positive.

The overall effect of all of these influences cannot be predicted with confidence, ${ }^{87}$ but some basis exists for a tentative conclusion that adding the possibility of a fee shift against individual litigants relying on their own resources might well result in a greater tendency to settle claims once pursued than exists under the American rule. The main support for this prediction comes from the likely strength of risk aversion, particularly when it is combined with the threat of a loss that may force a party into debt, or come out of modest savings with which one may be especially reluctant to part, for uncertain chance of gain. In this limited sense, the casual forecasts that fee shifting will encourage settlements seem likely to be at least partly right, though they were often made for the wrong reasons. With risk aversion less of a factor, as in much commercial litigation or often under oneway shifting, the cross-cutting considerations are too indeterminate in their relative impacts to permit any degree of confidence forecasting their net effect.

Finally, a word about the potential significance of the effects on the tendency to settle: Since the vast majority of cases are settled without trial, even a small change in the percentage settled could make a large difference in the number

84. See R. POSNER, supra note $31, \S 21.4$, at 437 ; Shavell, supra note 3 , at $68-69$ (risk aversion promotes settlement; this effect is strongest with the English rule, intermediate with one-way rules, and weakest under the American rule).

85. See supra text accompanying notes 61-63.

86. See generally, e.g., D. Kahneman \& A. Tversky, Choices, Values and Frames 22-26 (Nov. 29, 1983) (unpublished paper presented at National Academy of Sciences Symposium on Knowledge in Social and Behavioral Science).

87. See, e.g., Posner, supra note 39, at 418-20 (interrelation of parties' expenditures, along with their effect on expectations, creates indeterminacy concerning conditions for settlement). 
remaining for trial. ${ }^{88}$ A one percent increase in the settlement rate from $95 \%$ to $96 \%$, for example, would mean a $20 \%$ reduction in the number of cases going to trial, assuming, as always, no other changes follow. (The possibility of such changes cannot be disregarded; for example, a reduction in the waiting time for trial dates due to an increase in settlements caused by fee shifting could make insisting on trial more attractive for parties with cases remaining on the docket.) Since trials tend to consume the largest amount of judges' time, and a considerable amount of lawyers' time, any significant change in trial rates could have a major impact on workloads and congestion.

2. Timing of Settlement. The literature contains a fair amount of speculation that the American rule fosters delay and that fee shifting should speed dispositions. ${ }^{89}$ The thinking runs parallel to some of the reasoning behind casual predictions of increased likelihood of settlement-and suffers from the same fallacy of failing to take into account the effects on both sides. The weaker side may be in a greater hurry to settle because it foresees liability for the mounting costs of both sides rather than just its own. Yet, fee shifting liberates the stronger side to a parallel extent from the concern about incurring further unrecoverable expenses which it must weigh under the American rule. As fee shifting pushes one side to want earlier settlement, it gives the other side reason to be less eager to settle quickly. In the absence of vigorous judicial use of fee shifting against delaying $\operatorname{tactics}^{90}$ or of an offer device - to be considered later-it seems that with risk neutral adversaries the likely net effect of the basic incentives created by fee shifting on the timing of settlements should be regarded as indeterminate rather than positive.

Moreover, to a very considerable extent incentives for speed or delay are quite independent of fee shifting systems. Defendants facing large damage liabilities will often want to put off the day of reckoning, while injured plaintiffs facing current bills will normally be eager to collect as soon as possible. Lawyers are under different incentives to hurry matters along or drag them out depending, among other things, on their caseloads and whether their fee arrangements are hourly or contingent percentage. ${ }^{91}$ Insurance adjusters will often feel personal and company

88. See Conard, The Economic Treatment of Automobile Injuries, 63 MiCH. L. REV. 279, 286 (1964).

89. See, e.g., Goodhart, Costs, 38 YALE L.J. 849, 876 (1929) (incentives for defendants to use delay as a tactic to improve settlement bargaining position); Kuenzel, supra note 48, at 78 (same); Comment, supra note 39, at 167 (fee shifting provides incentives against delay).

90. Fee shifting can be used against dilatory tactics both under provisions targeted on specific abuses, such as those in the Federal Rules of Civil Procedure on discovery, and through judicial discretion to reduce fee awards under general shifting schemes. Such discretion could add a powerful weapon to the judiciary's often ineffective arsenal of devices usable to combat delay.

91. See generally, e.g., Clermont \& Currivan, supra note 9.

Whatever the influence of lawyers' particular incentives, if fee shifting has the effect of increasing lawyer involvement in some types of cases (see supra text accompanying note 37), that involvement itself might contribute to delay. Studies by and of the insurance industry indicate that whatever else the virtues of the legal profession, speeding settlements is not one of them. See AlL-INDUSTRY RESEARCH ADVISORY Committee, Automobile InJuRies and Their Compensation in the UntTed States 13 (1979); H. Ross, supra note 18, at 228-29. These studies found cases without lawyers involved settling faster than those with lawyers; the industry study, moreover, found that lawyer involvement did not produce higher net recovery for the client. 
pressure to keep their case backlogs from getting too large. ${ }^{92}$ The gap between the parties' original expectations will often be so great that no settlement will be possible until the completion of a good deal of discovery, no matter what the fee shifting policy and its effect.

The prospect of mounting legal fees, by itself, will always give the parties some incentive for speedy resolution; the main effect of a change in fee shifting policy is simply to affect the relative weight of the economic pressure on the different parties, not to eliminate it from the scene or to affect significantly the many other considerations favoring delay. Other incentives for speed or delay, then, are strong and independent; the likely effects of fee shifting policies seem in comparison to be relatively modest and ambiguous. This combination of considerations should make us wary of assertions that one fee shifting policy or another will significantly foster expedition or delay of dispositions. ${ }^{93}$

Despite all these caveats, it remains possible to make some modest predictions. First, when risk aversion is prominent enough, fee shifting should act to accelerate settlement, particularly with plaintiffs of modest means. The change from the American rule to two-way shifting could expose such parties to a risk they do not now face at all, since the change could be from the lawyer's bearing nearly all the risk of defeat under present contingent fee arrangements to the client's sharing it by being liable for a shifted fee. Moreover, the client would face increasing risk as the case continued and the other side's fees ran up. ${ }^{94}$ And, in contrast to some other fee shifting effects already discussed, the influence of risk aversion on one party will normally not be counterbalanced by an opposite impact on the other side.

Second, a key contribution of fee shifting could come in the reduction of dilatory tactics if it were used vigorously to penalize unjustified steps in litigation without regard to ultimate success or failure in the case as a whole. ${ }^{95}$ The use of fee shifting as a sanction against such tactics in this country, though often authorized, generally has not been vigorous. ${ }^{96}$ Without such sanctions as a basis for variance from any general rule, there may not be enough deterrence against the use of dilatory tactics by either side. An overall winner under a general fee shifting scheme should no more be able to force an adversary to absorb the costs of responding to harassing tactics than should a similar litigant under the American rule.

92. See $H$. Ross, supra note 18 , at $206-07$.

93. A possible exception is an offer of judgment device affecting liability for post-offer fees. See infra text accompanying note 125 .

94. The existence of such risks, of course, might well lead to the spread of legal expense insurance, see supra note 63, which would have its own effects, see, e.g., Blankenburg, supra note 29; Pfennigstorf, supra note 37 , at $78-81$.

95. See, e.g., Mattis, supra note 47, at 170-71; Mause, supra note 3, at 36-37; Note, Use of Taxable Costs to Regulate the Conduct of Litigants, 53 Colum. L. REV. 78, 94 (1953). See generally Note, Discovery Abuse Under the Federal Rules: Causes and Cures, 92 YaLE L.J. 352 (1982).

96. See, e.g., C. Ellington, A Study of Sanctions for Discovery Abuse 46-47, 74-76 (1979); R. Rodes, K. Ripple, \& C. MoOney, Sanctions Imposable for Violations of the federal Rules of Civil Procedure 85-86 (1981). 
3. Terms of Settlement; Discounting of Claim Amounts Because of Attorney Fees. Turning from possible effects on the timing of settlement to influences on the amounts at which settlement agreements may be reached, it becomes easier to develop hypotheses with some degree of confidence. Indeed, some of the influences that speculative predictions assume will affect settlement rate or timing may actually have their greatest impact on neither of these, but instead on the amount for which the parties settle. ${ }^{97}$ If the parties remain more or less the same amount apart, their likelihood of settling remains about the same, whether the range is moved up or down by a fee shifting policy. If one party is more willing to settle and the other less so, they may well settle at about the same time with fee shifting as they would have without it. If, however, fee shifting exists and the plaintiff has a very strong claim, his confidence of collecting close to the full amount of the claim, if shared by the defendant, makes it highly likely that settlement will come at a higher amount than under the American rule.

It may thus seem surprising at first that the literature contains predictions of both more and less discounting under fee shifting than under the usual American practice. Advocates of shifting claim that defendants could no longer insist on paying less than a strong claim warranted on its merits. ${ }^{98}$ Skeptics express concern that fee shifting would actually give defendants an even stronger hand than they now have and enable them to force plaintiffs into accepting inadequate settlements. ${ }^{99}$ Initially it may seem even more surprising that both are probably right, at least for two-way shifting; moreover, to the extent that the English rule does permit greater discounting, that effect may not be an especially telling criticism of such a system.

In order to sort out these paradoxes, a background explanation may be useful. Adjustments of claim amounts in settlement negotiations can occur, personal factors and bargaining skills aside, for two main types of reasons-uncertainty over the results of trial (liability, damages, or both) and allowances for the effect of attorney fees. At first leaving fees out of account, if we have a disagreement over $\$ 10,000$, but agree that I have a $75 \%$ chance of collecting it in court, settlement at $\$ 7,500$ would be economically rational. This kind of probable-outcome discounting will always be one element in settlement calculations conducted in economically rational terms. Introduce unrecoverable expected trial fees of $\$ 2,000$ for each side with still the same shared $75 \%$ estimate for plaintiff's success, however, and the bargaining span under the American rule runs from $\$ 5,500$ (my expected net gain from trial) to $\$ 9,500$ (your expected net loss). If you represent an insurance company and $I$ am an injured victim in need of money to pay medical bills, you will be in a strong position to insist that I settle for what I would net, rather than gross, from going to trial. Indeed, insurance companies sometimes do make

97. Cf. H. Zeisel, H. Kalven, \& B. Buchholz, Delay in the Court 128-40 (1959) (predicting, contrary to common expectations, that an award of interest from the day of the accident would affect price, rather than rate, of settlements).

98. See, e.g., Avilla, supra note 65, at 43; Kuenzel, supra note 31, at 87; Rothschild, A New Deal on Costs, 39 Сом. L.J. 43, 43, 44 (1934).

99. See, e.g., Morris, The Insurance Pinciple: Compulsory Insurance, in UNIVERsity OF ChICACO LAW SchoOl Conference on Insurance 173, 181 (1954); Comment, supra note 46, at 652. 
deductions from settlement offers for plaintiffs' expected trial costs. ${ }^{100}$

Taking these two principal factors into account, it is possible to make predictions about discounting under different fee rules. Under the pure American rule, for an overwhelmingly strong claim (agreed 100\% chance of success, sum certain) the bargaining span before any fees are incurred would run from the amount of the claim minus plaintiff's expected fees (which is what would permit a hard-bargaining defendant to try for a discount) up to the claim amount plus defendant's expected fees. The reverse of discounting is thus theoretically possible, but it is probably a rare plaintiff who can negotiate a defendant into paying more than some reasonable estimate of what a claim is worth on the merits. ${ }^{101}$ For a weaker claim, the span's size does not change so long as the parties agree on the likely outcome (or the gap between their estimates remains the same), since the span is then determined by the fees and they will not be shifted; the range moves down, however, to reflect discounting because of the estimates concerning the merits. ${ }^{102}$

With full and mandatory two-way fee shifting, the predictions for possible discounting would be quite different. For a claim that is a sure winner, plaintiff's expected net from trial is the full amount of his claim; defendant's expected net loss is that amount plus both sides' fees. The bargaining span, under these assumptions, is the same size as under the American rule (the sum of both sides' fees), but moved upward with its lower limit at the amount of the claim. In reality, things would seldom be quite so neat; a degree of uncertainty about even the strongest of claims would remain, at least with respect to the amount, as well as some disagreement between the parties. Often the parties would also have different risk preferences (e.g., risk-averse claimants and risk-neutral insurance company defendants) that introduce an element of bargaining advantage. Nonetheless, it should hold true that an upward shift of the bargaining span with strong claims will occur under two-way shifting; here lies the kernel of truth in the overgeneralized assertion that less discounting would be possible under the English approach.

For weaker claims under two-way shifting, however, effects could run in the opposite direction. ${ }^{103}$ In addition to the usual discounting for the weakness of the claim, the probability of a fee shift in the defendant's favor would move the bargaining span below the level prevailing when each side bears its own fees. ${ }^{104}$

100. See H. Ross, supra note 18 , at 213-14.

101. But see Phillips \& Hawkins, Some Economic Aspects of the Settlement Process: A Study of Personal Injury Claims, 39 MOD. L. REV. 497, 510-11 (1976) (possibility of overcompensation of strong small claims due to high processing costs). Cases involving strong liability claims with indefinite damages also might provide situations in which hard-bargaining plaintiffs can force settlements up because of defendants' expected litigation costs. The injustice of the possibility of inflating damages for threatened fees not incurred supports the existence of some sort of offer device.

102. One way in which it may be helpful to view the possibility of discounting strong claims under the American rule is that such a practice corresponds for defendants to what a nuisance suit is for plaintiffs. A nuisance plaintiff, who on the merits should expect to get little or nothing, possibly can extract a moderate settlement amount because of what it would cost the defendant to litigate. Similarly, a recalcitrant defendant facing a very strong claim should by "rights" have to pay all or nearly all of the plaintiffs claim; again, the threat of unrecoverable litigation costs, this time to the plaintiff, opens for the other side the chance of getting away for something less.

103. See Mause, supra note 3 , at 55 .

104. With risk-neutral parties, the point at which the bottom of the span under two-way shifting falls below where it would have been under the American rule comes when the plaintiff's chance of suffering an 
Returning to the example of the disputed $\$ 10,000$ claim, suppose the defendant foresees a $25 \%$ chance of losing and the plaintiff believes he has a $40 \%$ chance of winning. If each side's fees will be $\$ 2,000$, without shifting the bargaining span runs from $\$ 2,000$ to $\$ 4,500$ (defendant's weighted assessment of the likely outcome of trial is a $\$ 2,500$ loss, plus the $\$ 2,000$ he will not recover in fees; plaintiff's expected gain from suit is $\$ 4,000$, reduced by the same $\$ 2,000$ in fees). Introduce full two-way shifting, however, and the span shifts downward to run from $\$ 1,600$ to $\$ 3,500$ (defendant has the same verdict expectation but now only a probable $\$ 1,000$ loss on fees- one chance in four of having to pay the $\$ 4,000$ for both sides; and plaintiff must reduce his expected $\$ 4,000$ gain by $\$ 2,400$, for the $60 \%$ chance of having to pay the $\$ 4,000$ in fees).

One way of describing in intuitive terms how these effects should work is that, under the American rule, each side has to reckon with the certainty of absorbing its own fees; with two-way shifting, the calculation has to be based on the likelihood of paying the fees of both sides. When, with strong claims, that likelihood favors the plaintiff, he is better off than with no shifting; when it favors the defendant, as with weaker claims, the shoe is on the other foot. The effects will be especially strong when the threat of higher costs faces a party who is risk averse. ${ }^{105}$ Unless risk aversion is so pronounced as to lead to heavy discounting even of fairly strong claims, however, it would not be objectionable if fee shifting resulted in some increase in the discounting of claims that are not particularly strong, especially if that effect were accompanied by less discounting of the most meritorious claims.

The predictions about discounting under a one-way approach follow readily from the same type of reasoning, with intermediate results. For strong claims, the situation is very similar to that under two-way shifting except that the plaintiff's position is even stronger because of the protection against an adverse shift; there should be less discounting of such claims in settlements than under the American rule $^{106}$ and-though perhaps to a very limited extent-somewhat less discounting than under two-way shifting as well. For weak claims, the situation should be rather similar to that under the American rule, since each side could expect to bear its own fees; discounting could occur but based mainly on an assessment of the merits and not enhanced by the danger of plaintiffs' having to bear the fees of both sides in the event of defeat. In particular, one-way shifting should eliminate the strongest effects of risk aversion among plaintiffs that would be significant under a two-way rule.

\section{B. With Offer of Judgment Device}

Many procedural systems have devices that, in effect, enable parties to formalize a settlement offer and expose an adversary to cost consequences for

adverse fee shift, times the expected amount of both sides' fees, exceeds plaintiff's own likely lawyer's fee. If the two sides' fees would be equal, that point comes when the chance of an adverse shift rises above $50 \%$.

105. See, e.g., Williams, supra note 13, at 862 ; Comment, supra note 46 , at 652 ; H. Ross, supra note 18 , at 214-15 (advantage of risk-neutral insurer in bargaining with risk-averse claimant).

106. See Priest, supra note 57, at 166 (one-way pro-plaintiff rule moves bargaining span upward compared to American rule). 
rejecting it and not doing better at trial. The most common name for such devices in this country is "offer of judgment"; they are also referred to as "offers of settlement" or, in England, "payment into court" or just "payment in." The best known version of the device in American systems is in Rule 68 of the Federal Rules of Civil Procedure and in many counterpart state rules. Such rules often refer in terms only to "costs" and leave it unclear whether they cover attorney fees; it remains unsettled to what extent an offer under Federal Rule 68 can affect attorney fees, ${ }^{107}$ though recently proposed amendments would eliminate that uncertainty and extend the Rule to cover fees. ${ }^{108}$ Offer devices can work in different ways depending on the underlying fee shifting rule. They can make a shift possible when none would otherwise occur, as under the American rule (if, say, the defendant rejects the plaintiff's offer and the plaintiff then does better at trial, plaintiff will recover fees ${ }^{109}$ ). Where fee shifting already exists, as in England, offer devices can cancel or even reverse a shift that would otherwise take place. ${ }^{110}$

The commonly cited purpose of and expectation for such rules is to encourage settlements. ${ }^{111}$ If a party rejects a reasonable offer and does not do well enough at trial to justify the rejection, the reasoning goes, that party will suffer added consequences which should make it all the more inclined to be reasonable in considering the offer; a positive incentive exists as well for the offeror to make the offer a reasonable one. Such rules also seem to reflect a sense of procedural justice: if a party was willing to settle the case on reasonable terms, as measured by the result of trial, it should not have to suffer financially for its adversary's unjustified stubbornness in forcing the case to be carried further.

For all the nice theory, in this country offers of judgment have been much praised and little used. 12 Still, it is essential to consider their likely effects in connection with fee shifting; in England, where they do affect fee liability, defendants make considerable use of them. ${ }^{113}$ The use of offers of judgment will doubtless

107. Compare, e.g., Delta Air Lines v. August, 450 U.S. 346, 363 (1981) (Powell, J., concurring in result) ("the 'costs' component of a Rule 68 offer of judgment in a Title VII case must include reasonable attorney's fees accrued to the date of the offer"), with id. at 377 (Rehnquist, J., dissenting) (nothing suggests that Congress in the civil rights statutes "intended to amend Rule 68 by adding attorney's fees to otherwise taxable costs under that Rule"). See generally Note, Rule 68: A "New" Tool for Litigation, 1978 DUKE L.J. $889,898-902$

108. See supra note 11 .

109. See, e.g., WASH. Rev. CODE ANN. $\$ \S 4.84 .250-.280$ (West Supp. 1983).

110. See, e.g., Zander, supra note 12. In English practice, absent a payment into court, a plaintiff who secures any recovery would normally be entitled to recover counsel fees. But, if he fails to recover more than the defendant's payment in, he must pay the defendant's fees from the time of the payment. Where two-way shifting is already the norm, most systems seem to make no provision for formal offers by plain. tiffs; if a plaintiff beats the defense offer he will get his fees without regard to how much he demanded. British Columbia, however, has recently adopted a rule to try to give plaintiffs an incentive to make their own reasonable offers: if the defense rejects the plaintiff's offer and fails to get a better verdict, there is to be extra fee shifting in plaintiff's favor beyond the regular amount (which provides only partial reimbursement). See Gold, Controlling Procedural Abuses: The Role of Costs and Inherent Judicial Authority, 9 OTTAWA L. REV. 44, 69. (1977). See also Pfennigstorf, supra note 37, at 63 (West German practice of awarding prevailing plaintiff fraction of fees based on relation between initial demand and ultimate recovery).

111. See, e.g., Delta Air Lines v. August, 450 U.S. 346, 352 (1981); Note, Offer of Judgment and Statutorily Authorized Altomey's Fees: A Reconciliation of the Scope and Purpose of Rule 68, 16 GA. L. REV. 482 (1982); Note, supra note 107, at 889 \& n.3; Preliminary Draft, supra note 11, committee note, 98 F.R.D. at 363.

112. See Note, supra note 107 , at $889-90$.

113. See Zander, supra note 8. 
increase in the United States if the proposed amendments to Federal Rule 68 take effect. In some respects, though, trying to predict their effects is uncommonly complex, for offers greatly complicate calculations of the levels at which parties may settle.

A logical place to start is by trying to figure out what amount a party should offer, which is itself difficult because a fee-affecting ("formal") offer influences a party's expected net from trial. The party also faces the delicate consideration of going far enough but not too far. For example, a defendant wants to try to offer as much as possible in order to have the best chance of benefiting from fee shifting, but not so much that the plaintiff will happily snap up an unexpectedly generous offer that is higher than the defendant really wants to pay. ${ }^{114}$ Further, a formal offer introduces disparity between expectations about results on the merits and about the likelihood of a fee shift. Without the offer device, a defendant may have been certain of being held liable, at least in some amount, and of having to pay a plaintiff's fees; with it, he may still be certain of liability but no longer of having to pay fees. Then if the other side can make an offer, the further complications of how to set the amount, and the effect that offer has, enter into consideration. Finally, formal offers do not usually preclude the possibility of "ordinary" offers that, like those at present, do not affect fees. ${ }^{115}$ It still seems feasible, all the same, to make some plausible observations about the likely effects of offer devices on the different kinds of settlement phenomena discussed in the preceding sections. ${ }^{116}$

1. Likelihood of Settlement. Most cases settle, and will settle whether or not an offer device is available or used. Consequently, one should be careful of making too much of whatever can be said about the probable effects of formal offers on the likelihood of settlement. ${ }^{117}$ It is worth considering their impact, though, in cases in which settlement is problematic but not out of the question. Surprisingly, strong reason exists to expect-contrary to the general assumption-that, at least in some situations, the availability and use of offer devices will not make parties more likely to settle. The main, and still quite positive and significant, effects of these devices may instead be to encourage earlier settlement and to provide parties with a means to combat efforts at discounting settlement offers for expected litigation costs. ${ }^{118}$ Indeed, in some cases it appears quite clear that an offer device should make the

114. Cf. Oesterle, Proposed Rule 68 on Offers of Setllement, CoRnell L.F., Feb. 1984, at 11, 12 ("In some cases the defendant may prefer making a Rule 68 offer that does not settle the case instead of a normal offer that would settle the case.'); Priest, supra note 57, at 175-76 (defendant likely to want to submit unacceptably low offer, to avoid paying offer amount and to keep chance of recovering costs).

115. See Oesterle, supra note 114 , at 12.

116. For two helpful discussions of the economics of offer devices, see Bowles, Economic Aspects of Legal Procedure, in The Economic Approach to LAw 191, 197-201 (1981); Phillips \& Hawkins, supra note 101, at 514 . The point made in both is that a formal offer device affecting liability for post-offer fees creates a discontinuity in the parties' expectations from trial. Everything on the wrong side of the offer is shifted by the total amount of fees a party must now expect to have to pay if the result of the trial is not more favorable than the offer.

117. As prior discussion noted, though, even a small impact on the overall settlement rate could have a significant effect on the number of cases to be tried. See supra text accompanying note 88.

118. These latter effects may account for much imprecise rhetoric about offer devices' tendency to encourage settlement and the apparent assumption that they should produce a higher rate of settlements. 
parties less likely to settle; a brief exploration of that point can help explain why it seems that one should not be too quick to assume that the device will contribute to a higher rate of settlements, at least absent strong risk aversion.

A first illustration presumes a system operating under the American rule but permitting both parties to make formal offers; if either side fails to do better than the other's offer at trial, that party will be liable for the other side's reasonable post-offer fees. Under such a scheme, in a case involving liquidated damages but disagreement about liability, it will be in the defendant's interest to make only a token formal offer of judgment, and in the plaintiff's interest to make a formal offer not significantly below the amount claimed. Because the result will be all or nothing, neither side improves its position to benefit from fee shifting by putting any compromise offer in the official form of an offer of judgment. Since the parties disagree about the likelihood of success on the merits, the addition of the possibility of fee shifting, which is tied to the outcome on the merits of the liability issue, pushes the parties even farther apart than they already were.

Without fee shifting, there was no room for disagreement about fees; each side could be sure it would bear its own. The offer device introducing the possibility of a fee shift, however, permits each side to think it has a good chance of getting the other to pay all the fees. Other things being equal, risk-neutral parties in such a situation are less likely to settle, since their improved expectations from trial provide reason for their "ordinary" offers in informal settlement negotiations to be less forthcoming than if no shifting were possible."19 This example is a particular instance of the general point developed earlier that fee shifting has a negative effect on the bargaining span in cases of "optimistic disagreement." Again, when parties have something added that they can and do disagree about, they will normally be less likely to settle.

The second illustration presumes a system operating under either the English two-way rule, or one-way shifting with a provision for defendants to recover postoffer fees (or at least escape an adverse shift) despite a plaintiff's verdict if the verdict is not more favorable to the plaintiff than a formal offer. A significant type of case in which the offer device, under such systems, should worsen the chances of settlement is one in which the parties agree about the chances of a finding of liability (most likely, a case in which liability is certain, or highly probable) but disagree on the amount of damages. Without a formal offer, the parties agree on the

119. Cf. Oesterle, supra note 114 , at 12 (even when claim is not for liquidated damages, "[a] riskneutral defendant may. . . prefer to make [an] unacceptable rule 68 offer rather than . . . an accept[able] non-rule 68 offer") (footnote omitted).

Since the device so clearly fails to serve its intended purpose in the situation discussed in the text, courts could have authority to deny fee shifting when there was serious dispute about liability combined with a token offer. (The proposed amendments to Federal Rule 68 would permit the federal courts to reduce awards "to the extent expressly found . . . with a statement of reasons, to be excessive or unjustified under all of the circumstances," and specify that "[c]osts, expenses, and interest shall not be awarded to an offeror found by the court to have made an offer in bad faith." Preliminary Draft, supra note 11, at 362-63.) If the idea underlying the device is to foster reasonableness in the making and consideration of settlement offers, it makes no sense to apply it when the offer was only a token effort to take advantage of the rule and its rejection was entirely reasonable. Cf. August v. Delta Air Lines, 600 F.2d 699 (7th Cir. 1979) (no abuse of discretion for court to refuse cost shifting under Federal Rule 68 when offer was token and liability open to serious dispute), aff d on other grounds, 450 U.S. 346 (1981). 
odds about fee shifting, leaving the bargaining span determined solely by their differences about the likely damages verdict. Once the defendant makes a formal offer, though, fee shifting goes from being tied to the liability result (on which the parties agree) to being linked with the damages outcome (about which they differ)-and that introduces a new element of disagreement between them, making settlement less likely. ${ }^{120}$

Putting the point of these two examples in general terms, in some cases the availability and use of an offer device can have a negative effect on the bargaining span and thus-again, other things being equal-make settlement less likely. ${ }^{121}$ Much of a party's incentive to make a formal offer comes, in fact, from the way the move will improve the party's expected net from trial, by increasing the likelihood of a shift in its favor or reducing the chance of a shift against it. Once it has accomplished this objective, further flexibility in settlement negotiations is less attractive than before-having made the offer, the party has reason to dig in. Even though the move will often worsen the other side's expected net from trial, the same impact-on-both-sides effect mentioned above frequently will keep the parties at least as far apart as before. ${ }^{122}$

If offer devices are to have any regular positive effect on the likelihood of settlement, it seemingly must come from sources that do not have offsetting impacts on both sides. Risk aversion and diminishing marginal utility of wealth do work that way, and the use of a formal offer can play on the concern of a risk-averse party for possible loss. In particular, a formal offer can introduce new uncertainty (possible fee liability) and widen the range of possible outcomes by creating a gap in the range. ${ }^{123}$ These effects increase the risk facing the recipient of the offer and play on concern for possible loss of savings; the result, in a case involving a party with sharply changing diminishing marginal utility of wealth and thus highly averse to the risk of substantial loss, would be to encourage settlement. Whether that effect would be more than enough to offset the negative impact of many formal offers on the bargaining span is unpredictable and would vary from case to case with the stakes and characteristics of the parties. If risk aversion and relevant diminishing marginal utility of wealth are widespread, as seems likely among middle-income litigants, the effect of making settlements more likely could be quite significant. ${ }^{124}$

120. Unlike the token offer problem discussed in the previous paragraph of the text, this type of situation does not seem to involve any abuse of the offer device calling for judicial discretion to make exceptions from its effect. Here, it does have the intended influences of drawing out reasonable offers and providing an incentive to be reasonable in considering them. It simply appears as well to have an unfortunate and unavoidable negative effect on the bargaining span.

121. See Priest, supra note 57, at 169-70.

One significant type of case in which such an effect could be important is litigation in which a party rejects a formal offer but later arrives at a less optimistic expectation of the results from trial. See Oesterle, supra note 114 , at 12 . The negative effect on the bargaining span could mean that the change in estimate moves the party with the revised expectation into what would have been agreement range before the offer but is not after it.

122. See Priest, supra note 57, at 170-71 (pointing out failure in some prior discussion to take into account effect of offer on defendant's as well as plaintiff's expected value of litigation).

123. See supra note 116.

124. See also Oesterle, supra note 114 , at 12 ("Presumably, the proposed rule will generate a net increase in settlements, because risk aversion will limit the number of choices against settlements in favor of rejected rule 68 offers."). 
It could, however, come at the cost of weakening the position of the one-shotter individual in litigation in relation to the stronger repeat player corporate or governmental party.

2. Timing of Settlement. Discerning the likely impact of offer devices appears less problematic when the focus shifts to the timing of settlements and the phenomenon of discounting. An offer device, at least when it affects only those fees incurred after the date of the offer, provides parties with an incentive to be realistic as early as possible. (If the offer affects all fees, it makes no difference in terms of its effect on fee shifting when it is made, eliminating a major part of the incentive to make realistic offers early.) The sooner a defendant, for example, makes a good offer, the less of plaintiff's fee bill it is likely to have to pay, and-if the rule so provides-the more of its own fee bill can the defendant hope to get paid. What offer devices may accomplish, then, whether or not they increase the likelihood of settlement, is to smoke out realistic offers early and help get cases that are going to be settled anyway settled sooner-which would be important both for the doing of justice and for the efficiency of the system. ${ }^{125}$

3. Terms of Settlement. Similarly, offer devices should have significant impact on the amount at which parties settle. Specifically, they should be very effective against efforts to use anticipated attorney fees as a way to give less, or gain more, than the merits seem to warrant in strong cases. To a defendant trying to discount a strong claim under the American rule, but with an offer device permitting fee shifting, a plaintiff could respond with a formal offer of settlement at or near 100 cents on the dollar; the defendant would then be in a bargaining position weakened much as if there were two-way or one-way shifting, perhaps enough to discourage the attempt at discounting in the first place. ${ }^{126}$ Yet, the plaintiff would be in a weaker position to try the blackmail that two-way or one-way shifting could permit if he were able to hold out for more than the case warrants because of defendant's likely liability for both sides' fees. If failure to do better than a formal offer permitted a reverse shift, defendant could protect himself fully by making a reasonable offer that the plaintiff would have little hope of beating at trial, squelching the effort to get anything more. Thus, offer devices give a party facing a hard bargainer leverage to force the negotiation away from the far extreme of their bargaining span, toward a point more in keeping with reasonable expectations about the outcome on the merits.

125. The incentive for the "smoke-out" effect described in text is clear enough-to recover one's fees from an earlier point in the litigation. A mix of other factors, however, could mean that realistic offers might not always come early. Before a good deal of discovery, for example, a defendant may simply not feel in a position to offer more than a token amount. Furthermore, a provision like the one in the proposed amendments to Federal Rule 68 requiring that an offer "shall remain open for 30 days unless a court authorizes earlier withdrawal," Preliminary Draft, supra note 11 , at 362 , could make parties hesitate to make serious offers without a high level of confidence in the completeness of the information on which they were based.

126. This effect of countering efforts to discount claims does mean, of course, that what would have been an acceptable settlement offer were there no offer rule might no longer be so. The generally healthy effect of reducing discounting might therefore come at the price of some reduction in the likelihood of settlements. 
Whatever the effects of offer devices on settlement, finally, it should not be forgotten that in significant ways they also further procedural and substantive justice. Procedurally, they let a party escape the costs of litigation stages that should not have been necessary. ${ }^{127}$ Substantively, an offer device permitting fee shifting under the American rule could encourage the presentation of some meritorious small claims by holding out the chance of indemnity from a recalcitrant defendant. Though offer devices can sometimes operate harshly, ${ }^{128}$ particularly when used against quite risk-averse middle-income parties, their significant positive effects in connection with the timing and amount of settlements and their appeal on grounds of fairness suggest that it is worthwhile to try to work out particular forms of the device that minimize its problems. ${ }^{129}$

\section{Conclusion}

The discussion in this article has attempted not just to survey the literature in an organized fashion but on some points to advance the level of our understanding. In its efforts to explore further the likely effects of attorney fee shifting, the article has tried to go beyond prior discussion in the following main respects: 1) explaining why "nuisance" litigation, despite some theoretical and practical objections, realistically can be a substantial phenomenon (and thus why fee policies affecting it might have a significant impact);130 2) breaking down the effects on settlement into three major types, those on likelihood, timing, and amount; ${ }^{131}$ 3) emphasizing the particularly strong effect of risk aversion and sharply changing diminishing marginal utility of income and wealth on litigants of modest means, who may be especially influenced by the threat of substantial loss introduced by fee shifting ${ }^{132}$; 4) discussing how both judicial discretion in fee award decisions and offer of settlement devices can mean that probabilities with respect to outcomes on the merits and fee awards can diverge; ${ }^{133}$ and 5) predicting the distinct effects that may be expected from the availability and use of offer devices. ${ }^{134}$

It would be nice to be able to offer, at the end of such a survey, a few main points in summary on the likely effects of attorney fee shifting schemes and a conclusion on the desirability of one or another. As I have discussed elsewhere, ${ }^{135}$ however, decisions on fee shifting policy depend not just on anticipated effects but also

127. But of. Oesterle, supra note 114 , at 13 ("it seems odd . . that with respect to reimbursement of attorney fees we can summon up more righteous indignation over a refused offer than over the act of injury itself').

128. See, e.g., P. Atiyah, Accidents, Compensation and the Law 308-11 (3d ed. 1980).

129. See generally, e.g., Geller, Unreasonable Refusal to Settle and Calendar Congestion-Suggested Remedy, 1962 A.B.A. Sec. Int'l \& Comp. Law, Proceedings 134, 134-38; Zander, Is the English Payment-into-Court Rule Worth Copying?', 40 RABELS ZEITSCHRIFT FÜR AUSLANDISCHES UND INTERNATIONALES PRIVATRECHT 751, $757-58$ (1976).

130. See supra text accompanying notes 48-60.

131. See supra text accompanying notes 64-126.

132. See supra note 19 and text accompanying notes $61,85-86,123$

133. See supra note 71 and text accompanying notes $114,120$.

134. See supra text accompanying notes 107-29.

135. See Rowe, supra note 2 . 
on ideas of fairness and social goals. If this survey has made anything clear, moreover, it is that the effects we can expect are so multifarious that any conclusion would be oversimplified. One participant at the 1982 Duke conference commented that as for "whether fee shifting should be adopted as a matter of public policy," this paper "takes the debate to the point at which we can be fairly certain that we will never know."136 I hope the prospects are not that bad, and that this discussion can be of some use in the making of policy on attorney fee shifting-or if they are so daunting, that this article has at least advanced our understanding of the reasons why. in a forthcoming article, Rowe, supra note 9. 
